\title{
APPLICATION OF LASER GONTROLLED NANOPARTICLES IN WASTE WATER TREATMENT
}

\author{
Y.A. Badr' , M.S. Mousa and M.E. Zain Elabedien c
}

a National Institute of Laser Enhanced Science, Cairo University, Cairo, Egypt

b Sanitary Engineering Department, Faculty of Engineering, Helwan University, EI Mataria, Egypt

c National Institute of Laser Enhanced Science,

Cairo University, Cairo, Egypt 


\section{APPLICATION OF LASER CONTROLLED NANOPARTICLES IN WASTE WATER TREATMENT}

\author{
Y.A. Badr ${ }^{a}$, M.S. Mousa ${ }^{b}$ \\ and M.E. Zain Elahedien ${ }^{c}$ \\ ${ }^{a}$ National Institute of Laser Enhanced Science, Cairo \\ University, Cairo, Egypt \\ b Sanitary Engineering Department, Faculty of \\ Engineering, Helwan University, El Mataria, Egypt \\ ${ }^{c}$ National Institute of Laser Enhanced Science, Cairo \\ University, Cairo, Egypt
}

\section{Abstract:}

In the area of water purification, nanotechnology offers the possibility of an efficient removal of pollutants and germs. Today nanoparticle, nanomembrane and nanopowder are used for detection and removal of chemical and biological substances includes metals, nutrients, organics, viruses, bacteria, parasites antibiotics. Nonmaterial's reveal good result than other techniques used in water treatment because of its high surface area (surface/volume ratio). The aim of this work is to study effect of silver nanoparticle $\mathrm{Ag}$ NPs before and after photofragmentation as coagulant and as disinfectant in wastewater; this has been carried out through flocculation, coagulation, and disinfection techniques. Flocculation has been carried out using silver nanoparticle. Effect of each of the previous techniques on $\mathrm{PH}$, total dissolved solids, total suspended solids, biological oxygen demand, chemical oxygen demand ,total coliform and fecal coliform were studied considered The optimum practical conditions for each technique and for the whole study have been selected.
Keywords: Nanoparticles, photofragmentation, coagulant, disinfectant, biological oxygen demand, chemical oxygen demand.

\section{Introduction}

The most of the countries are facing drinking water problems in some countries there are very severe especially problem in developing countries. The world is facing formidable Challenges in meeting rising demands of clean water as the available supplies of freshwater are depleting due to (i) extended droughts, (ii) population growth, (iii) more stringent health based regulations and (iv) competing demands from variety of users. $(1,2,3)$.

The River Nile, the longest river in the world, is the main source of irrigation in Egypt. Historically, Egypt's rich agricultural land, with the exception of a few scattered oases in the desert, has consisted of the 1,200 km strip of the Nile River Valley and the Nile Delta. The annual per capita share of the country's water resources is approximately $875 \mathrm{~m}^{3}$, of which 84 percent is crop water demand, with the consumptive use being nearly 68 percent. Estimation of the municipal water use depends on population growth rates, the consumption in liter/Capita/day, and distribution system losses Expressed as conveyance efficiency Estimation of Municipal Water use. From February to September, water released from the High Aswan Dam (HAD) for irrigation, Municipal, and industrial purposes is sufficient to maintain the required navigational draft in the Nile (4, 5,6).Everyone generates wastewater. Today we recognize that we must recycle water to maintain sustainable supplies of safe drinking water for future generations. In order to clean up or treat wastewater for recycling, it is important to understand what Wastewater contains, what 
problems it may cause, and what it takes to clean it up. Chemically enhanced primary treatment (CEPT) is a wastewater treatment method that can also be used as an efficient preliminary step to biological secondary treatment (such as activated sludge and trickling filters). CEPT adopts the coagulation and flocculation processes and accomplishes a remarkable increase in the removals of common pollutants and contaminants such as BOD (biochemical oxygen demand), COD (chemical oxygen demand), and TSS (total suspended solids) present in the influent. In Egypt law 48 of 1982 necessitates secondary treatment of wastewater prior to disposal in water courses. This requires the achievement of relatively high levels of treatment. Secondary treatment (which is required to reach regulations limits) invariably uses biological treatment processes which require high operation and maintenance costs. Many types of chemicals have been studied as coagulants including alum, lime, ferric chloride and polymers. The main objective of the research is to investigate the effectiveness of the AgNPs controlled by laser (to different particles size) in wastewater line when used as coagulant in the measure of $\mathrm{PH}$, conductivity, removal percent of BOD, COD, TSS, TVS, total and fecal coliform from municipal wastewater then study the effect of AgNPs (with different sizes) as disinfectant on total and fecal colifrorms removal percent. And study the effect of it in sludge line by measure sludge volume index (SVI).

\section{Materials and methods}

Freshly collected sewage samples were distributed among the six jars after thorough mixing. Coagulant dosage was then added in varying proportions in each jar followed immediately by the initiation of flash mixing,
100 RPM. After 1 minute, mixing was reduced to 30 RPM and held at this level for 20 minute. Finally, a quiescent settling period of 30 minute was allowed. At the end of the settling period, a sample of the supernatant was analyzed for the various parameters. Jar testing experiments were carried out using three samples one taken from the effluent of the grit removal from Abu Rawash treatment plant (ARTP), samples two of return activated sludge (RAS) and samples three from effluent of Zenin wastewater plant. The specification of the instruments used for chemicals analyses are the TSS, TVS, BOD, COD, Conductivity, $\mathrm{PH}$, sludge volume index (SVI), Total coliform, Fecal coliform .

All experiments procedure According to procedure in standard methods for the examination of water and wastewater $20^{\text {th }} \mathrm{Ed}$.

\section{- silver nanoparticles AgNPs preparation :} preparation method of AgNPs. (according to Borohydride - Creighton Method )(8) used this chemical as follow:

Silver nitrate $\left(\mathrm{AgNo}_{3}\right)$, Sodium Borohydride $\left(\mathrm{NaBH}_{4}\right)$, Sodium laureth sulfate

\section{- The characterization of silver nanoparticles Prepared by $\mathrm{NaBH}_{4}$}

Silver NPs prepared by chemical method were investigated using UV-Visible spectrophotometer and Transmission Electron Microscope (TEM). In previous work in our group we irradiated Ag NPs with $308 \mathrm{~nm}$ excimer laser. The maximum absorption and the full width at half maximum have been decreased as the number of pulses increased up to 100,000 pulses due to the size reduction. The Ag NPs irradiated with $308 \mathrm{~nm}$ excimer laser system see fig. (1). 
Silver NPs prepared by chemical method were investigated again after irradiation with 100,000 pulses (plus) of excimer laser 308 $\mathrm{nm}$ using UV-Visible spectrophotometer and Transmission Electron Microscope (TEM). These NPs had (have) different sizes.

The characterization of AgNPs (sample B) obtained by chemical reduction using $\mathrm{NaBH} 4$ is (in) given Fig. (2). Fig.2 (a) shows that the AgNPs are characterized by an absorption band at $409.5 \mathrm{~nm}$. The average size of the AgNPs is $21 \pm 5$ as seen in Fig2 (b).

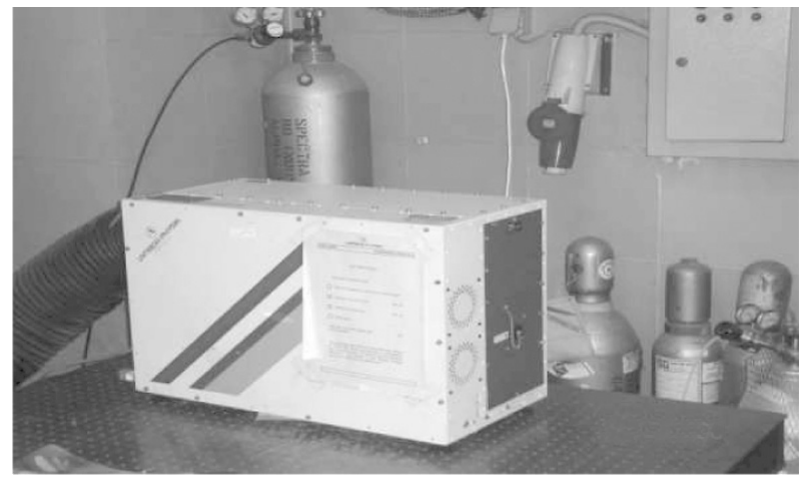

Fig. (1) excimer laser system
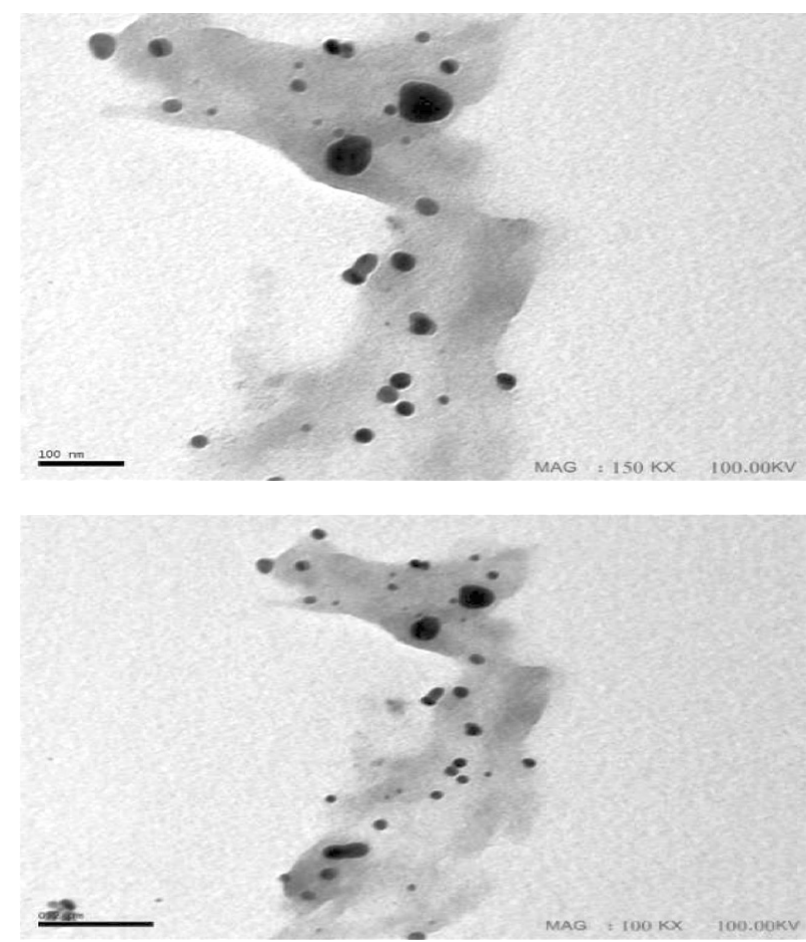

Fig. 2 (b). TEM of Ag

NP prepared chemically by $\mathrm{NaBH}_{4}$

And we find the characterization of second sample of AgNPs (sample,c) obtained by chemical reduction using $\mathrm{NaBH}_{4}$ is (in) given Fig(3). Fig.3(a) shows that the AgNPs are characterized by an absorption band at $410 \mathrm{~nm}$. The average size of the AgNPs is $20 \pm 3$ before photofragmentation and 18 after photofragmentation as seen in Fig. 3(b). 
Data Set: Storage 100325 - RawData - C:IDocuments and

Settings\AdministratorlDesktopIFile_Sample 1.spc

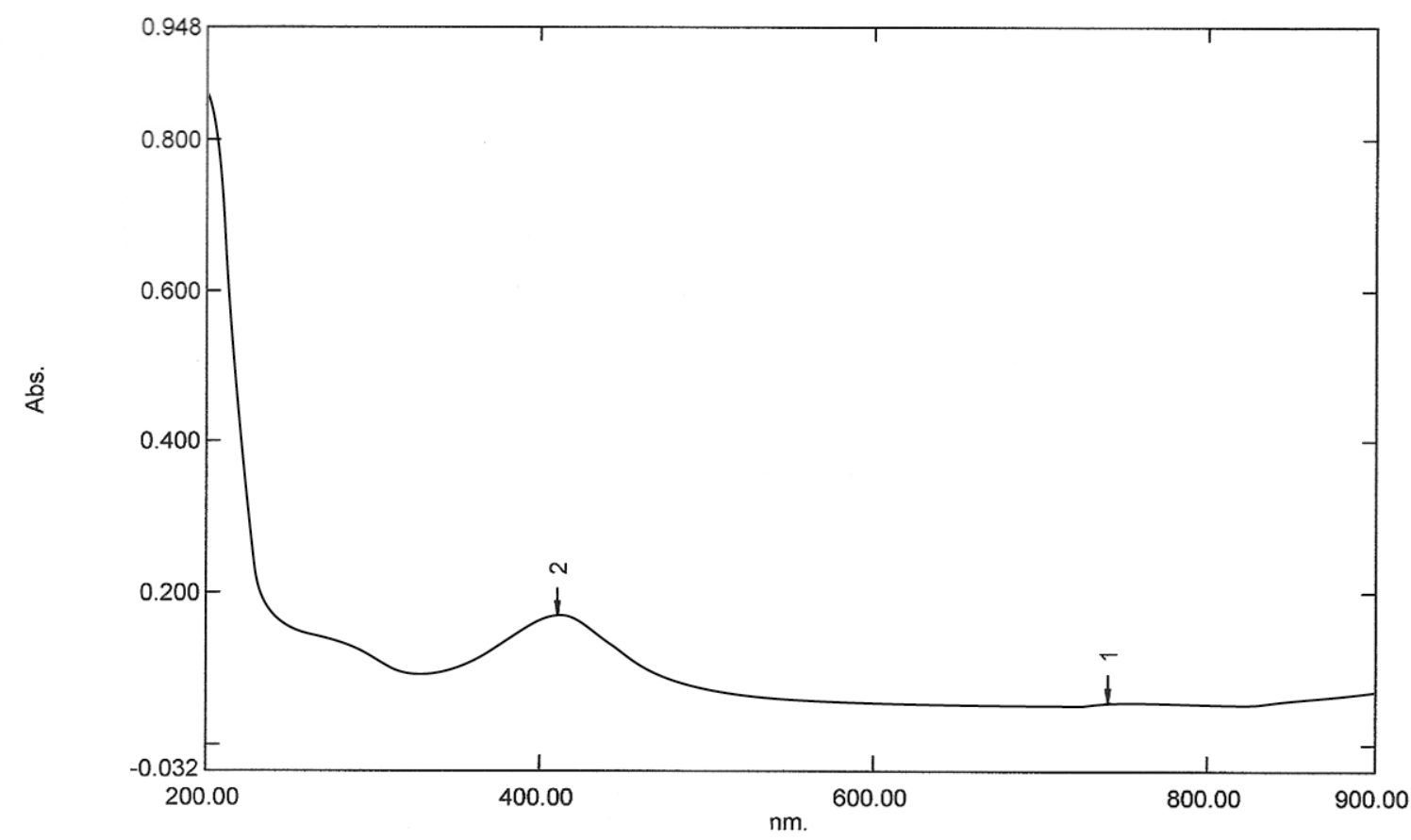

Measurement Properties

Wavelength Range ( $\mathrm{nm}$.)

200.00 to 900.00

Scan Speed:

Sampling Interval:

Fast

0.5

Enabled

Scan Mode:

Single

\begin{tabular}{|r|c|r|r|r|}
\hline \multicolumn{1}{|c|}{ No. } & P/N & Wavelength & Abs. & Description \\
\hline 1 & $\uparrow$ & 739.50 & 0.057 & \\
\hline 2 & $\uparrow$ & 410.50 & 0.172 & \\
\hline 3 & $\oplus$ & 809.00 & 0.051 & \\
\hline 4 & $\oplus$ & 328.50 & 0.093 & \\
\hline
\end{tabular}

Sample Preparation Properties

Weight:

Volume:

Dilution:

Path Length:

Additional Information:

Instrument Properties

Instrument Type:

Measuring Mode:

Slit Width:

328.50

0.093

Light Source Change Wavelength:

S/R Exchange:

UV-1600 Series

Absorbance

$2.0 \mathrm{~nm}$

$340.8 \mathrm{~nm}$

Normal

Attachment Properties

Attachment:

None

Page 1/1

Fig. 2 (a). UV/Visible spectrum of $\mathrm{Ag}$

NP prepared chemically by $\mathrm{NaBH}_{4}$ 


\section{Spectrum Peak Pick Report}

\section{Data Set: Storage 100644 - RawData - C:IDocuments and} Settings\AdministratorlDesktoplFile_Sample 2.spc

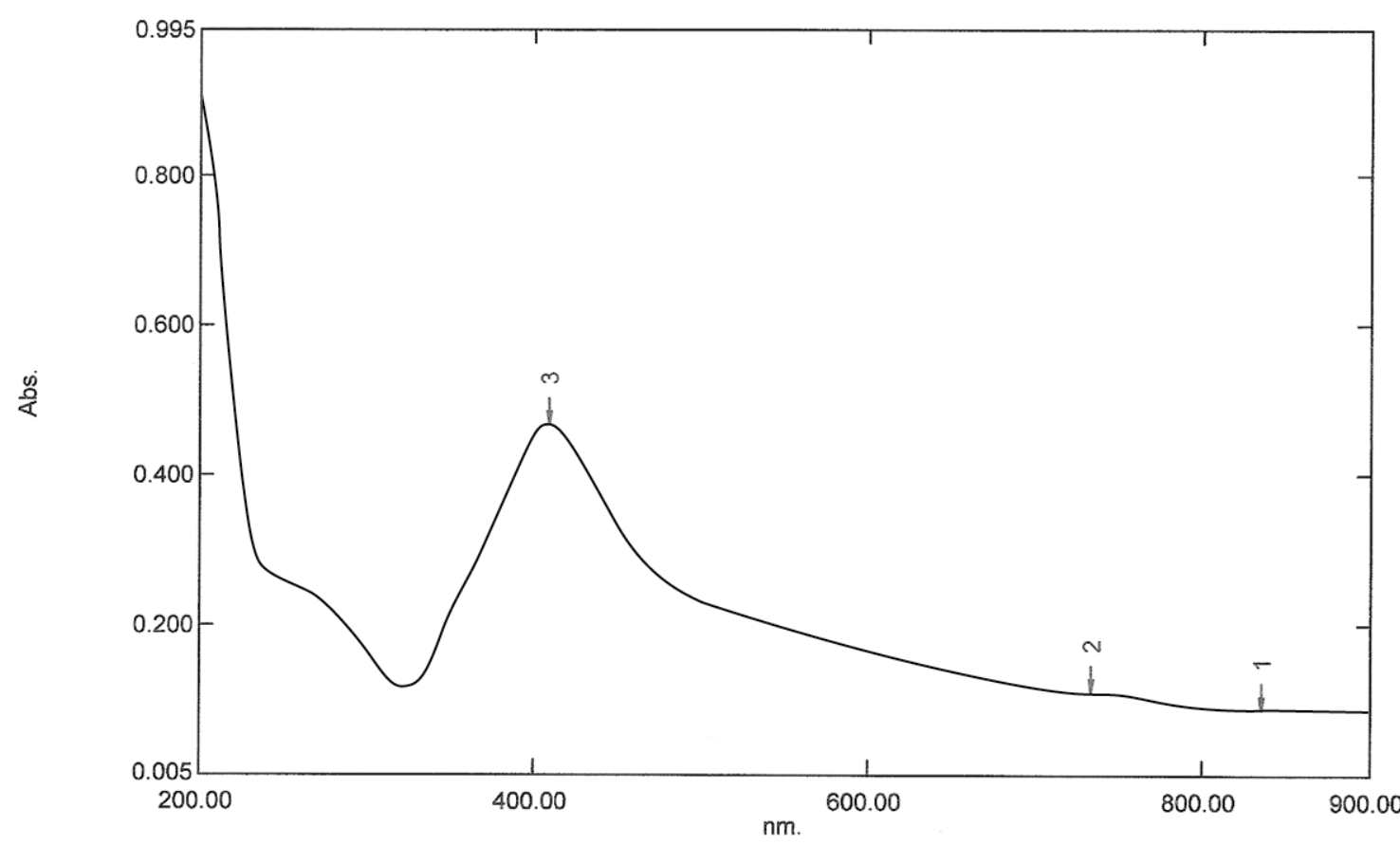

Measurement Properties

Wavelength Range ( $\mathrm{nm}$.):

Scan Speed:

Sampling Interval:

200.00 to 900.00

Auto Sampling Interval:

Fast

0.5

Scan Mode:

Single

Sample Preparation Properties

Weight:

Volume:

Dilution:

Path Length:

Additional Information:

Instrument Properties

Instrument Type:

Measuring Mode:

Slit Width:

UV-1600 Series

Absorbance

$2.0 \mathrm{~nm}$

Light Source Change Wavelength: $340.8 \mathrm{~nm}$

S/R Exchange:

Normal

Attachment Properties

Attachment:

None

\section{Page $1 / 1$}

Fig.3(a) uv/visible spectrum of AgNP

prepared chemically by $\mathrm{NaBH}_{4}$ 


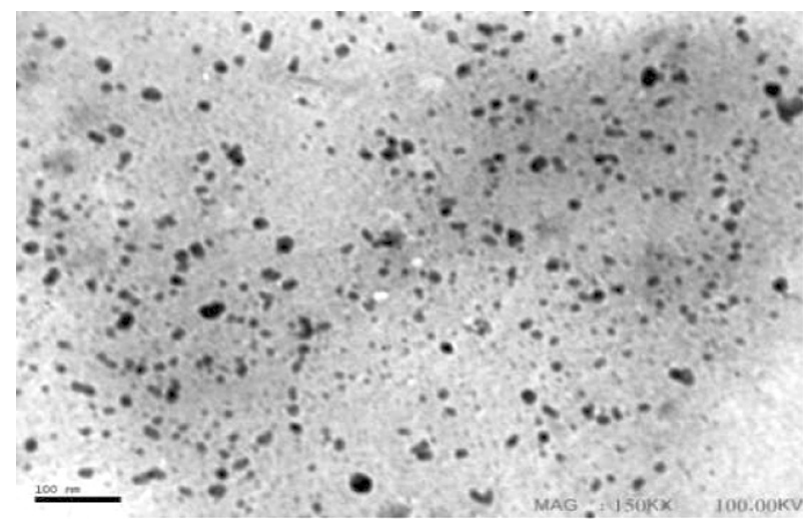

Fig. 3 (b). TEM image of Ag NPs prepared by $\mathrm{NaBH}_{4}$ with the size of particles equal to $20 \pm 5 \mathrm{~nm}$

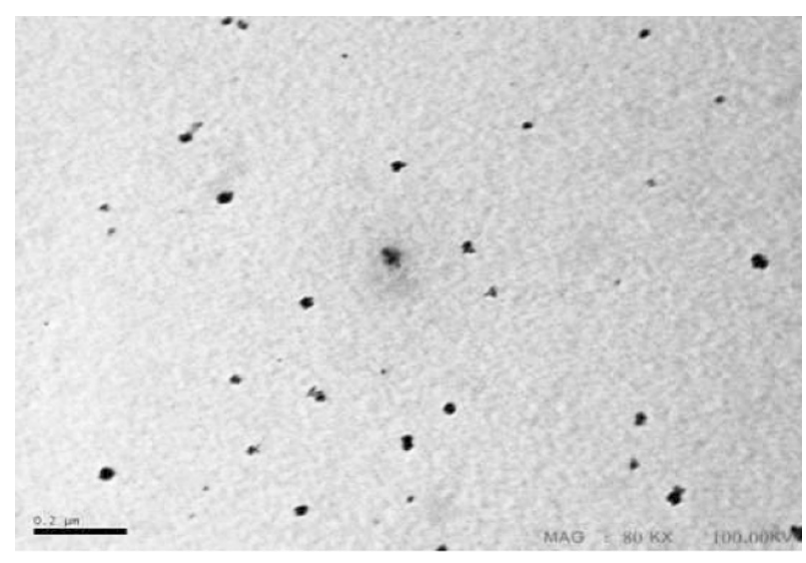

Fig.3(c). TEM of Ag NPs after irradiation by 100,000 pulses of excimer laser,

The size of particles is equal to $18 \pm 3 \mathrm{~nm}$

\subsection{3 laser-induced photofragmentation of Ag NPs:}

The absorption of Ag NPs for the visible light are mainly due to the coherent oscillations of the free electrons from one surface of the particles to the other (i.e. surface Plasmon resonance)(9). the Ag NPs exposed to $193 \mathrm{~nm}$ pulsed excimer laser undergo photofragmentation into small particles, the TEM photographs of the Ag NPs taken before and after the irradiation with 10 thousand pulses. as in figure 3.(b,c)

\subsubsection{Mechanism of photofragmentation:}

The nanoparticles undergo photofragmentation after laser excitation into smaller fragments; the mechanism of photofragmentation was summarized in fig.(4).
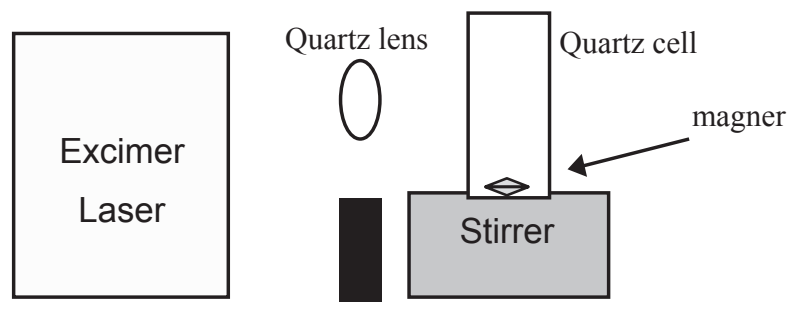

fig. (4). the setup used in photofragmentation of Ag NPs

The excimer laser beam interacts with the nanoparticles leads to photoejection of electrons and formation of transient aggregate .The transients is highly unstable and undergo fragmentation due to the repulsion between positively charged particles (10),(11) .

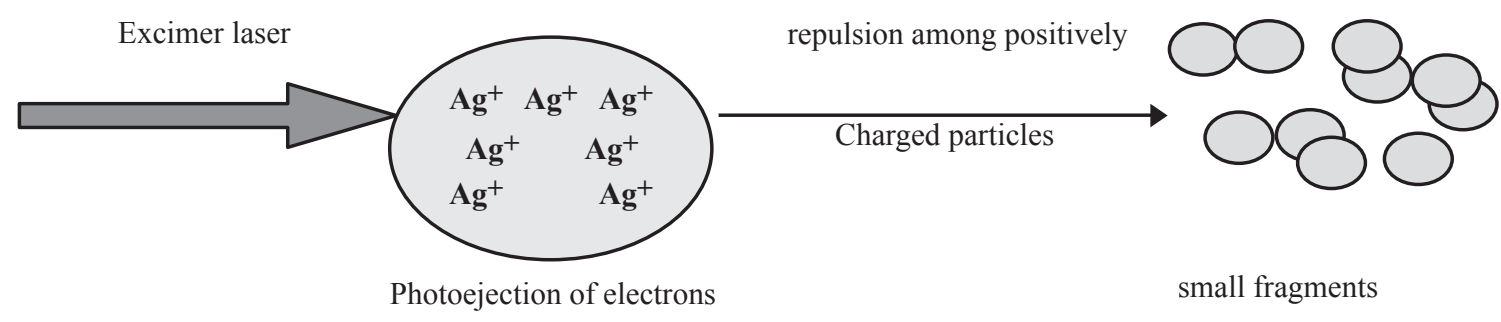

Fig. (5). mechanism of photofragmentation process 


\section{Results \& Discussion:}

Results of our research will be presented in accordance with the work plan, samples Locations and analysis in terms of tables and curves. The analysis carried out for all experiments are shown in table(1a,1b).while the work plan for all trials in table (2).

Table (1): analysis carried out for each trial

Table (1.a): analysis carried out for each trial using as coagulant:

\begin{tabular}{|c|c|c|c|c|c|c|c|c|c|c|}
\hline $\begin{array}{l}\text { Trial } \\
\text { NO. }\end{array}$ & $\begin{array}{l}\text { Coag. } \\
\text { Type }\end{array}$ & $\mathrm{PH}$ & TSS & BOD & COD & Cond. & TVS & SVI & $\begin{array}{c}\text { Total } \\
\text { coliform }\end{array}$ & $\begin{array}{c}\text { Fecal } \\
\text { coliform }\end{array}$ \\
\hline 1 & \multirow{6}{*}{$\begin{array}{l}\text { AgNPs } \\
(21 \mathrm{~nm})\end{array}$} & घ & घ & घ & घ & घ & - & - & - & घ \\
\hline 2 & & घ & घ & घ & घ & घ & - & - & - & $\Delta$ \\
\hline 3 & & - & घ & - & $\Delta$ & घ & घ & घ & $\Delta$ & $\Delta$ \\
\hline 4 & & E & a & 口 & a & 口 & - & . & $\Delta$ & $\Delta$ \\
\hline 5 & & $\Delta$ & - & - & - & $\Delta$ & $\Delta$ & - & $\Delta$ & $\Delta$ \\
\hline 6 & & $\Delta$ & - & - & - & $\Delta$ & $\Delta$ & - & $\Delta$ & $\Delta$ \\
\hline 7 & \multirow{2}{*}{$\begin{array}{l}\text { AgNPs } \\
(20 \mathrm{~nm})\end{array}$} & $\Delta$ & घ & - & - & $\Delta$ & $\Delta$ & $\Delta$ & $\Delta$ & $\Delta$ \\
\hline 8 & & $\Delta$ & - & - & घ & $\Delta$ & $\Delta$ & $\Delta$ & $\Delta$ & $\Delta$ \\
\hline \multirow[t]{2}{*}{9} & \multirow{2}{*}{$\begin{array}{l}\text { AgNPs } \\
(18 \mathrm{~nm})\end{array}$} & $\Delta$ & घ & च & घ & $\Delta$ & $\Delta$ & $\Delta$ & $\Delta$ & $\Delta$ \\
\hline & & $\Delta$ & - & - & - & $\Delta$ & $\Delta$ & $\Delta$ & $\Delta$ & $\Delta$ \\
\hline घ & Carried ou & & & & & & & & Not c & ied out \\
\hline
\end{tabular}

Table(1. b): work plane for each trial

\begin{tabular}{|c|c|c|c|c|}
\hline Trial No. & Test type & Flash mix & Slow mix & $\begin{array}{l}\text { Settling time } \\
\text { (minute) }\end{array}$ \\
\hline 1 & \multirow{10}{*}{ Coagulant } & \multirow{10}{*}{1 min.@100rpm } & \multirow{10}{*}{$\begin{array}{l}20 \mathrm{~min} . \\
\text { @3 } 30 \mathrm{rpm}\end{array}$} & \multirow{10}{*}{$30 \mathrm{~min}}$. \\
\hline 2 & & & & \\
\hline 3 & & & & \\
\hline 4 & & & & \\
\hline 5 & & & & \\
\hline 6 & & & & \\
\hline 7 & & & & \\
\hline 8 & & & & \\
\hline 9 & & & & \\
\hline 10 & & & & \\
\hline 11 & \multirow{3}{*}{ disinfectant } & \multirow{3}{*}{15 min.@250rpm } & \multirow{3}{*}{--------------- } & \multirow{3}{*}{---------------- } \\
\hline 12 & & & & \\
\hline 13 & & & & \\
\hline
\end{tabular}


Table(2 ): analysis carried out

Using as disinfectant

\begin{tabular}{|c|c|c|c|}
\hline $\begin{array}{l}\text { Trial } \\
\text { NO. }\end{array}$ & $\begin{array}{c}\text { Disinfectant } \\
\text { Type }\end{array}$ & $\begin{array}{c}\text { Total } \\
\text { Coliform }\end{array}$ & $\begin{array}{c}\text { Fecal } \\
\text { Coliform }\end{array}$ \\
\hline 11 & $\begin{array}{l}\text { AgNPs } \\
(21 \mathrm{~nm})\end{array}$ & घ & घ \\
\hline 12 & $\begin{array}{l}\text { AgNPs } \\
(20 \mathrm{~nm})\end{array}$ & घ & घ \\
\hline 13 & $\begin{array}{l}\text { AgNPs } \\
(18 \mathrm{~nm})\end{array}$ & च & घ \\
\hline \multicolumn{3}{|c|}{ Carried out } & \\
\hline
\end{tabular}

In order to study the effect of AgNPs in wastewater treatment, it was thought here worthwhile to select the optimum dose of AgNPs (with different sizes) giving the best results for AgNPs (=21nm) as coagulation and disinfectant, and the results showed that:

\section{** Treatment methodology results:}

Our results study the effect of AgNPs with different sizes in

- Water line : study of the effect of AgNPs as coagulant by measuring TSS, $\mathrm{BOD}_{5}, \mathrm{COD}, \mathrm{PH}$, Cond., TVS, total and fecal coilforms. And then study the effect of AgNPs as disinfectant by measuring total and fecal coliforms.

- Sludge line : study of the effect of AgNPs on sludge by measuring sludge volume index (SVI) .

\section{1) $\operatorname{AgNPs}(21 \mathrm{~nm})$ treatment results as coagulation.}

\subsection{1) Effect of $\operatorname{AgNPs}(21 \mathrm{~nm})$ on TSS.}

The following charts shows the changes occurred as a result of $\operatorname{AgNPs}(21 \mathrm{~nm})$ dose Treatment.

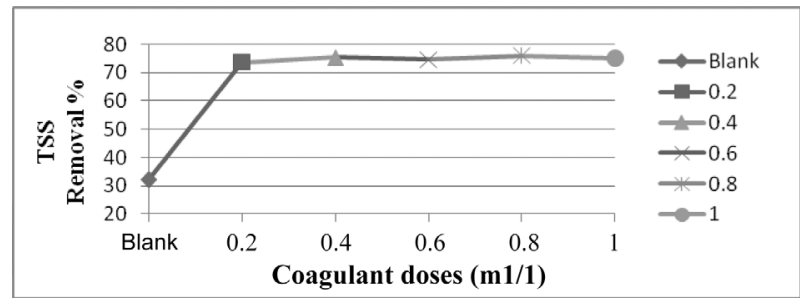

Figure (6) :Effect of AgNPs (21nm) on TSS removal \%

\subsection{2) Effect of $\operatorname{AgNPs}(21 \mathrm{~nm})$ on BOD :-}

Figure (7) illustrates $\operatorname{AgNPs}(21 \mathrm{~nm})$ doses influence on BOD, showing that a Influence has been achieved at $0.8 \mathrm{ml} / 1$ in which the removal percent is $(53.85 \%)$ then started to decrease.

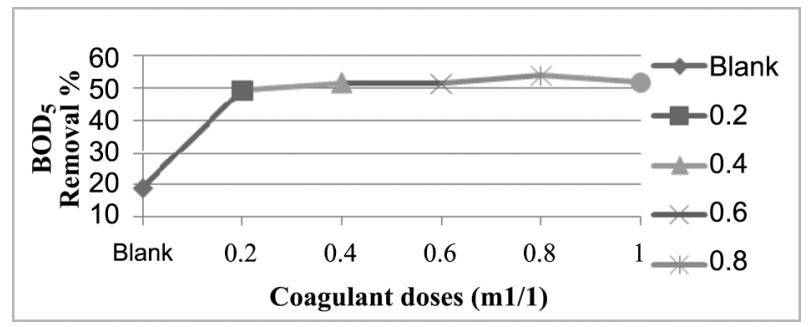

Figure (7) :Effect of AgNPs (21nm) on BOD removal

\subsection{3) Effect of $\operatorname{AgNPs}(21 \mathrm{~nm})$ on COD:-}

Our results showed that the effect of AgNPs $(21 \mathrm{~nm})$ on COD decreases by increasing dose .The removal efficiency decreases by increasing dose. the high removal efficiency obtained at dose $(0.2 \mathrm{ml} / 1)$.

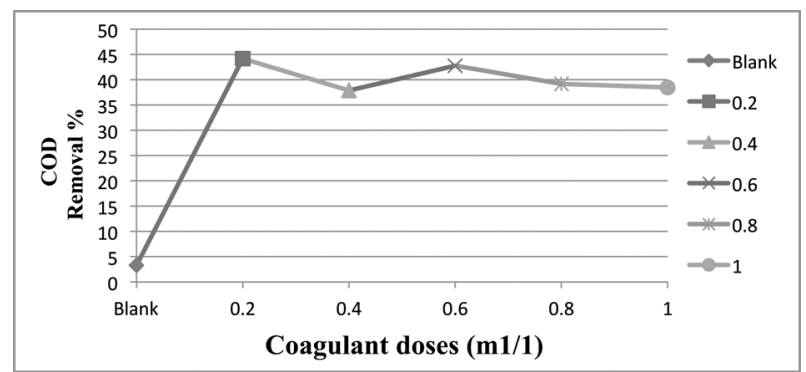

Figure (8) :Effect of AgNPs (21nm) on COD removal \%

\subsection{4 ) Effect of $\operatorname{AgNPs}(21 \mathrm{~nm})$ on PH .}

Figure (9) showed that illustrates the effect of $\operatorname{AgNPs}(21 \mathrm{~nm})$ on PH was no further change has been recorded after adding of different doses.

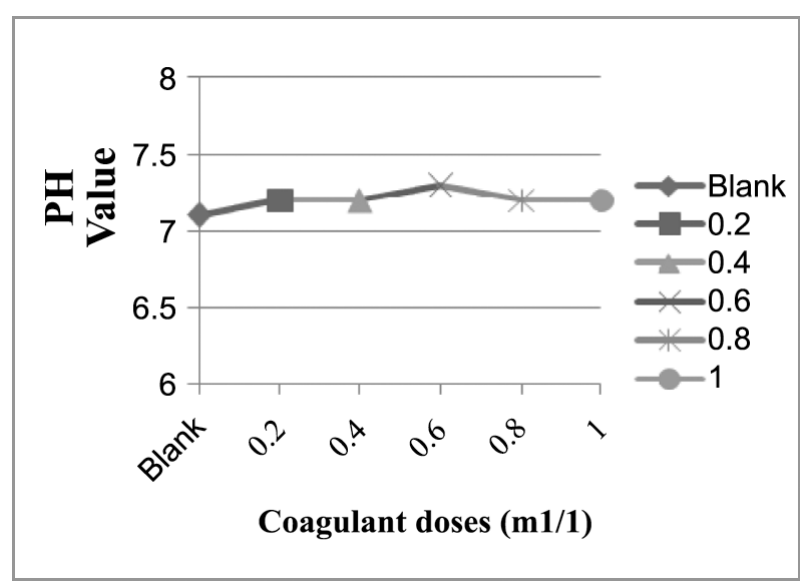

Fig. (9):Effect of $\operatorname{AgNPs}(=21 \mathrm{~nm})$ on $\mathrm{PH}$ 


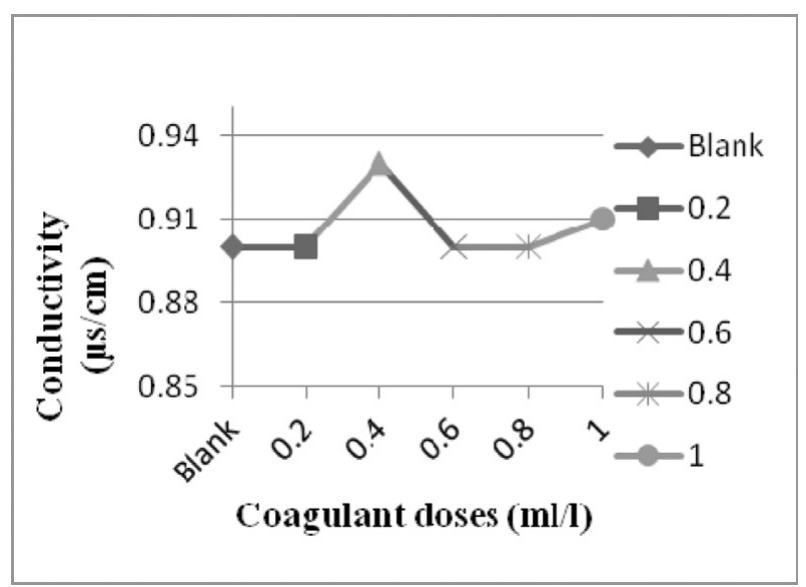

fig. (10): Effect of $\operatorname{AgNPs}(=21 \mathrm{~nm})$ on conductivity

\subsection{5) Effect of $\operatorname{AgNPs}(21 \mathrm{~nm})$ on Conductivity.}

It is obvious from figure (10) that illustrates the effect of $\operatorname{AgNPs}(21 \mathrm{~nm})$ on conductivity was no further change has been recorded after adding of different dose

\subsection{6 ) Effect of $\operatorname{AgNPs}(21 \mathrm{~nm})$ on total volatile solids (TVS) .}

figure (11) showed that the variation of the removal efficiency with the dose. It is clearly shown that the removal efficiency increases as the dose increases up to a dose $0.4 \mathrm{ml} / 1$ thereafter the efficiency decreased as the dose increased indicating that $0.4 \mathrm{ml} / 1$ is the optimum dose for TSS removal

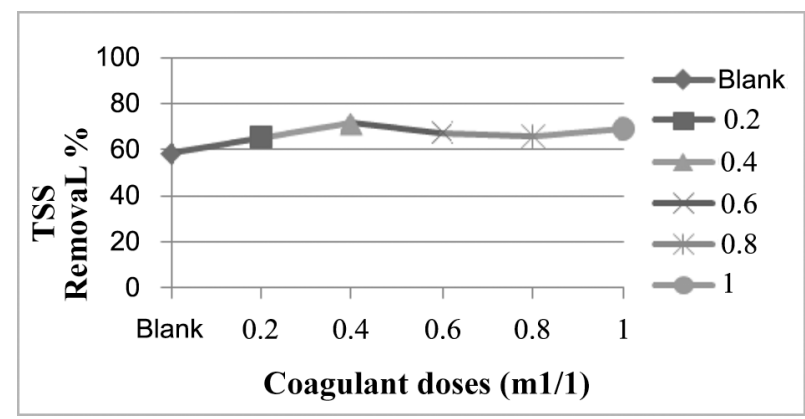

Fig. (11):Effect of $\operatorname{AgNPs}(=21 \mathrm{~nm})$ on TVs

Table (3):Effect of $\operatorname{AgNPs}(=21 \mathrm{~nm})$ on coliforms group

\begin{tabular}{|c|c|c|c|c|c|c|c|c|}
\hline & TEST & Blank & $\mathrm{S}+0.2$ & $\mathrm{~S}+0.4$ & $S+0.6$ & $\mathrm{~S}+0.8$ & $S+1.0$ & INF. \\
\hline \multirow{4}{*}{ 1) } & \multirow{2}{*}{$\begin{array}{c}\text { TOTAL } \\
\text { COLIFORM/100ml }\end{array}$} & $200 * 10^{4}$ & $34 * 10^{4}$ & $100 * 10^{4}$ & $81 * 10^{3}$ & $55^{*} 10^{4}$ & $64 * 10^{4}$ & $13^{*} 10^{4}$ \\
\hline & & REMOVAL \% & $83 \%$ & $50 \%$ & $96 \%$ & $73 \%$ & $68 \%$ & $94 \%$ \\
\hline & \multirow{2}{*}{$\begin{array}{c}\text { FECAL } \\
\text { COLIFORM } / 100 \mathrm{ml}\end{array}$} & $104 * 10^{4}$ & $26^{*} 10^{4}$ & $79 * 10^{4}$ & $14 * 10^{3}$ & $51 * 10^{4}$ & $41 * 10^{4}$ & $10^{*} 10^{4}$ \\
\hline & & REMOVAL \% & $75 \%$ & $24 \%$ & $85.5 \%$ & $51 \%$ & $60.6 \%$ & $90.4 \%$ \\
\hline \multirow{2}{*}{ 2) } & \multirow{2}{*}{$\begin{array}{c}\text { TOTAL } \\
\text { COLIFORM } / 100 \mathrm{ml}\end{array}$} & $68 * 10^{6}$ & $14 * 10^{6}$ & $19 * 10^{6}$ & $13 * 10^{6}$ & $20 * 10^{6}$ & $23 * 10^{6}$ & $6 * 10^{6}$ \\
\hline & & REMOVAL \% & $79.4 \%$ & $72.1 \%$ & $80.9 \%$ & 70.6 & $66.2 \%$ & $91.2 \%$ \\
\hline
\end{tabular}




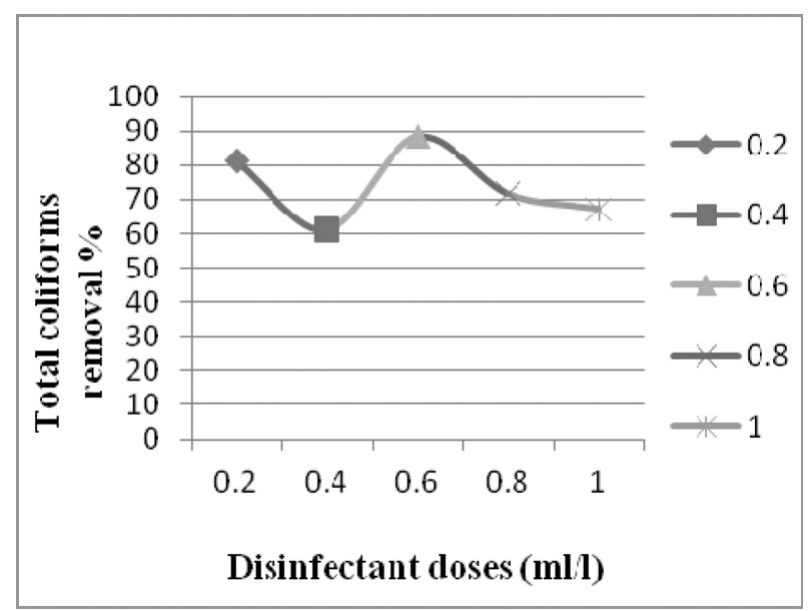

Figure (12) :Effect of AgNPs (21nm) on total coliforms removal $\%$

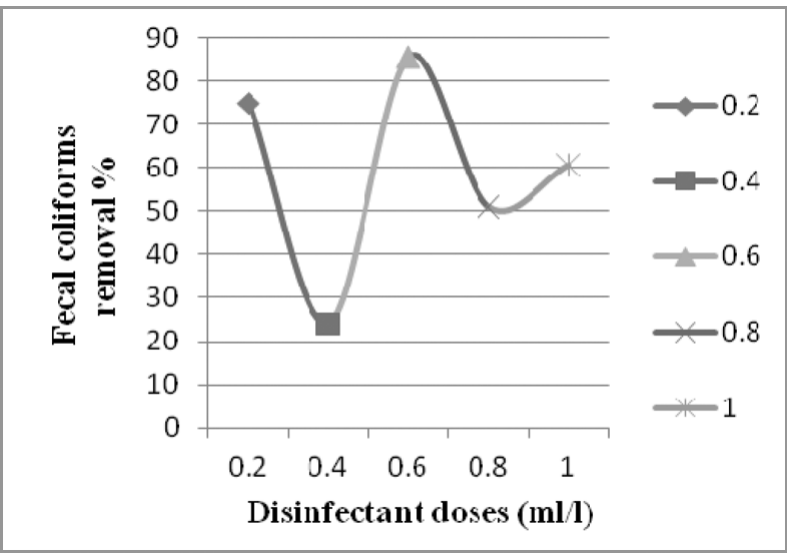

Figure (13) :Effect of AgNPs (21nm) on fecal coliforms removal $\%$

Figure (12) show that by increasing dosage, the removal eff. Increases up to $0.6 \mathrm{ml} / 1$ which correspond to removal of pathogens by $80.9 \%$ and then started to decrease. So the optimum dose removal for total coliforms is $0.6 \mathrm{ml} / 1$.

Figure (13) shows that by increasing dosage, the removal efficiency increases up to $0.6 \mathrm{ml} / 1$ which corresponding to removal of pathogens from fecal coliforms by $85.5 \%$ and then started to decrease. So the optimum dose for removal fecal coliforms the same as that's for total coliforms .
1.2) $\operatorname{AgNPs}(21 \mathrm{~nm})$ treatment results as disinfectant :

\subsection{1) Effect of AgNPs (21 nm) In Effluent of abu Rawash treatment plant:}

By taking Samples from eff. of Abu Rawash treatment plant and put it in A jar test and stir it for (15 minute) by (250 r.p.m) we find,

Figure (14) shows that removal percent of pathogens (total and fecal coliforms ) is reached to $100 \%$ for fecal and total coliforms by adding $1.0 \mathrm{ml} / 1$ of chlore, but by adding $1.0 \mathrm{ml} / 1$ of AgNPs $(21 \mathrm{~nm})$ the removal percent reached to $44.12 \%$ for total coliforms and to $98.3 \%$ for fecal coliforms

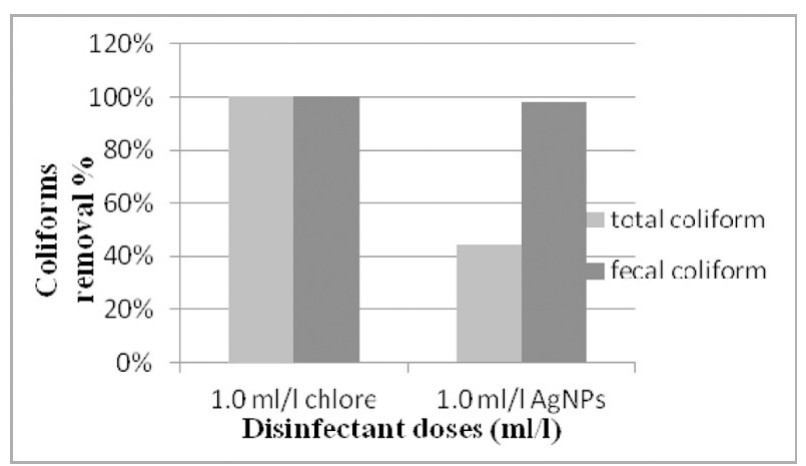

Figure (14) :Effect of chlore \& AgNPs (21nm) on choliforms removal $\%$

\subsection{2) Effect of AgNPs (21 nm) In Effluent of Zenin treatment plant:}

By taking Samples from eff. of Zenin treatment plant and put it in A jar test and stir it for (15 minute) by (250 r.p.m) we find that,removal percent of pathogens (total and fecal coliforms) reached to $99.1 \%$ for total and $100 \%$ for fecal coliforms by adding $1.0 \mathrm{ml} / 1$ of chlore, but by adding $1.0 \mathrm{ml} / \mathrm{l}$ of AgNPs $(21 \mathrm{~nm})$ the removal percent reached to $73.1 \%$ for total coliforms and to $45.7 \%$ for fecal coliforms and this is clearly seen in figures (15) \& (16) . 


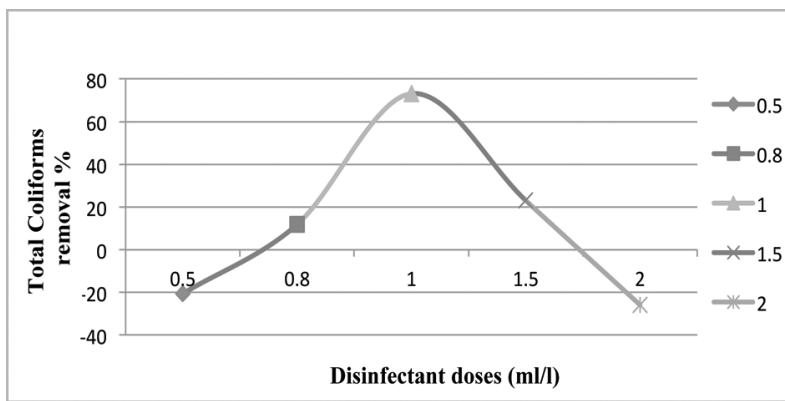

Figure (15) :Effect of AgNPs (21nm) on total coliforms removal $\%$

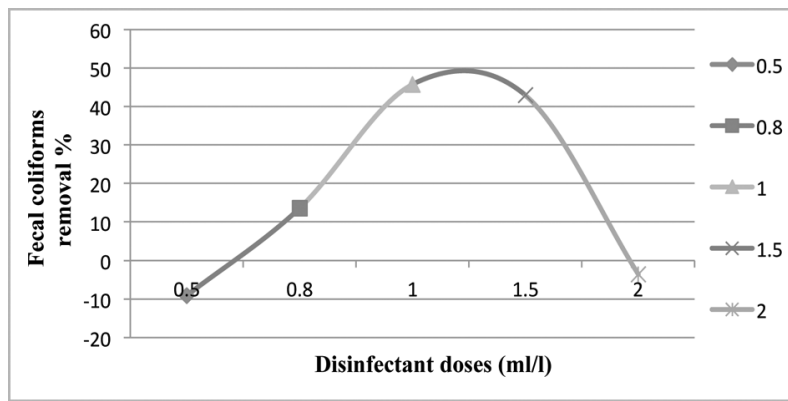

Figure (16) :Effect of AgNPs (21nm) on fecal coliforms removal $\%$

\section{3) Effect of $\operatorname{AgNPs}(21 \mathrm{~nm})$ on sludge line :} to study the effect of AgNPs $(21 \mathrm{~nm})$ on sludge line we collected samples from Zenin plant (from return activated sludge) and measured sludge volume index (SVI) before and after adding different doses of AgNPs (21nm) as show in fig.(17) .

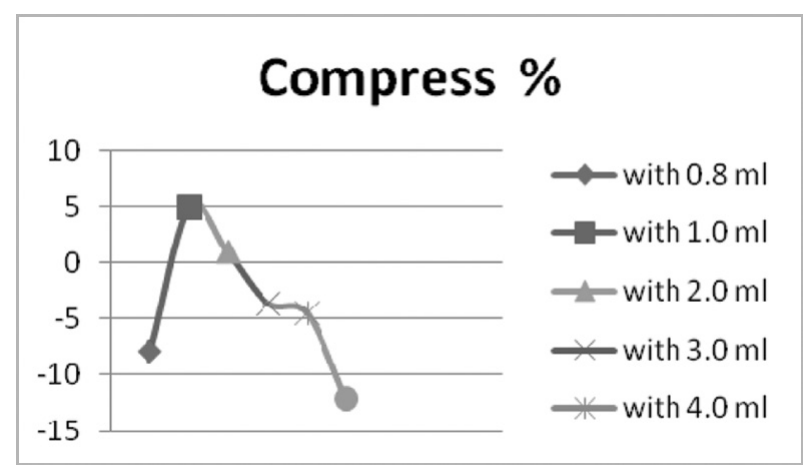

Figure (17) :Effect of AgNPs (21nm) on compress of sludge $\%$

the above figure showed that the compress of sludge is decreased at first and then increased at $1.0 \mathrm{ml} / 1 \mathrm{which}$ it was optimum dose and then it gradually decreased

\section{4) Effect of AgNPs (type, C) on wastewater:}

In order to study the effect of AgNPs in wastewater treatment, it was thought here worth while to select the optimum dose of AgNPs (before and after photofragmentation ) giving best results for AgNPs (=20nm before photofragmentation) and AgNPs $(=18 \mathrm{~nm}$ after photofragmentation ) as coagulation and disinfectant, and the obtained here results can be summarized as follows :

\subsection{1) Effect of AgNPs (type,C) on} wastewater line :

1.4.1.1) Effect of AgNPs (type,C) as coagulant:

Table(4) :collection results of AgNPs as coagulation

\begin{tabular}{|c|c|c|c|c|c|c|}
\hline \multirow{2}{*}{ Test type } & \multicolumn{2}{|c|}{ TSS } & \multicolumn{2}{c|}{ BOD $_{5}$} & \multicolumn{2}{c|}{ COD } \\
\cline { 2 - 7 } & $\mathrm{mg} / 1$ & Rem. $\%$ & $\mathrm{mg} / 1$ & Rem. $\%$ & $\mathrm{mg} / 1$ & Rem. $\%$ \\
\hline Blank & 220 & 0 & 212.5 & 0 & 372 & 0 \\
\hline 0.4 bef. & 48 & 78.18 & 123.5 & 41.88 & 196 & 47.31 \\
\hline 0.4 aft. & 47.5 & 78.41 & 123 & 42.12 & 183 & 50.81 \\
\hline
\end{tabular}


Our results showed that effect of N-PS sized on the removal efficiency is not significant.

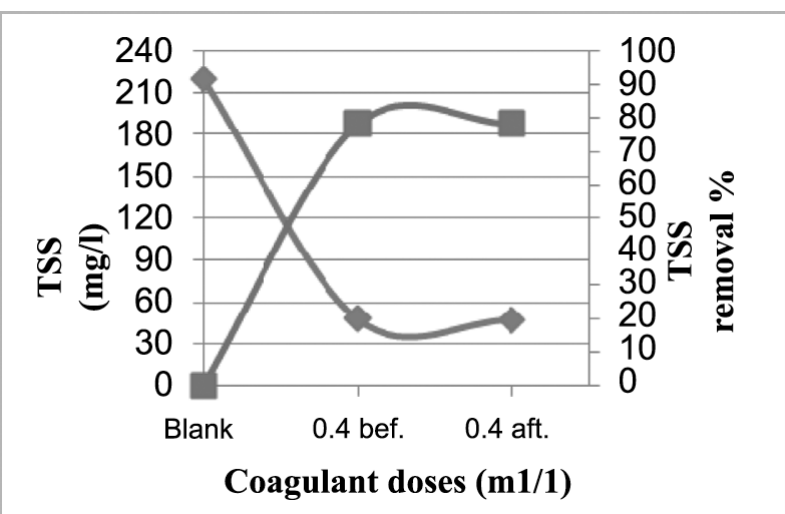

Figure (18) :Effect of AgNPs before and after photofragmentaion on TSS at optimum dose

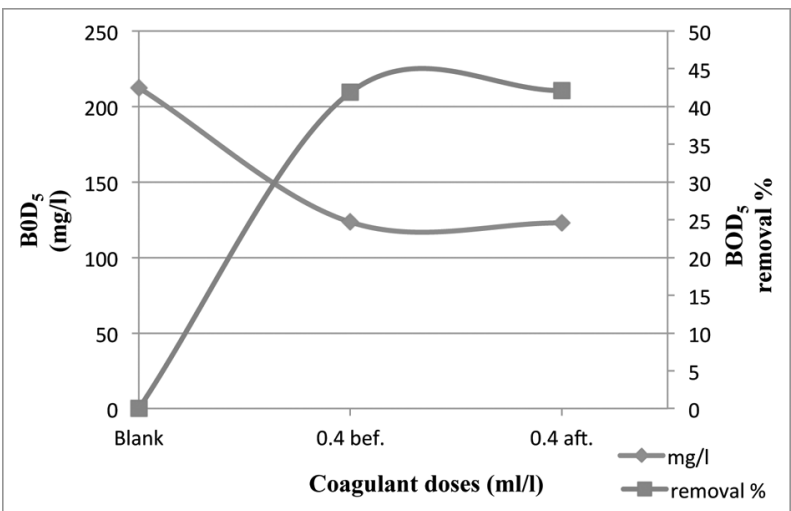

Figure (19) :Effect of AgNPs before and after photofragmentaion on $\mathrm{BOD}_{5}$ at optimum dose

figure (18) showed that after photofragmentation by using excimer laser on $\operatorname{AgNPs}(20 \mathrm{~nm})$ To produce $\operatorname{AgNPs}(18 \mathrm{~nm})$, the removal efficiency of total suspended solids increased from nearly $78.2 \%$ before photofragmentation to $78.4 \%$ after photofragmentation .i.e no significant increase obtained.

Figure (19) show after photofragmentation by using excimer laser on AgNPs $(20 \mathrm{~nm})$ To produce $\operatorname{AgNPs}(18 \mathrm{~nm})$, the removal efficiency of $\mathrm{BOD}_{5}$ increased from nearly $41.9 \%$ before photofragmentation to $42.1 \%$ after photofragmentation .

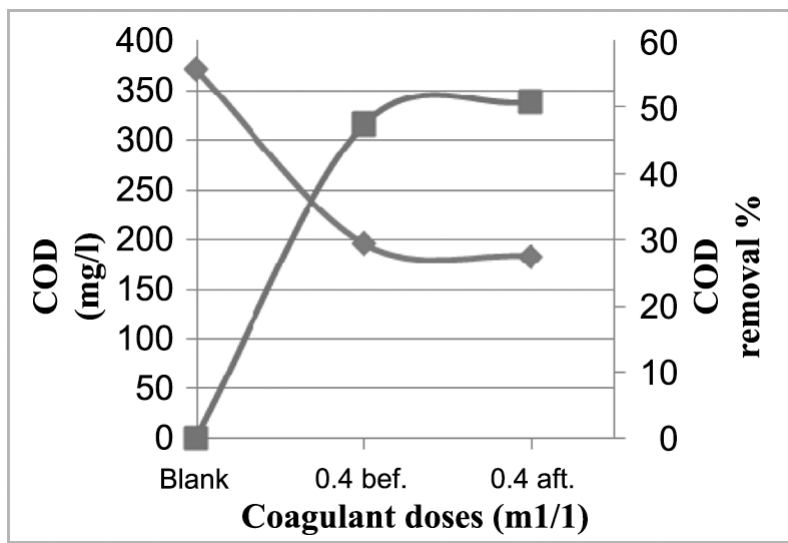

Figure (20) :Effect of AgNPs before and after photofragmentaion on COD at optimum dose

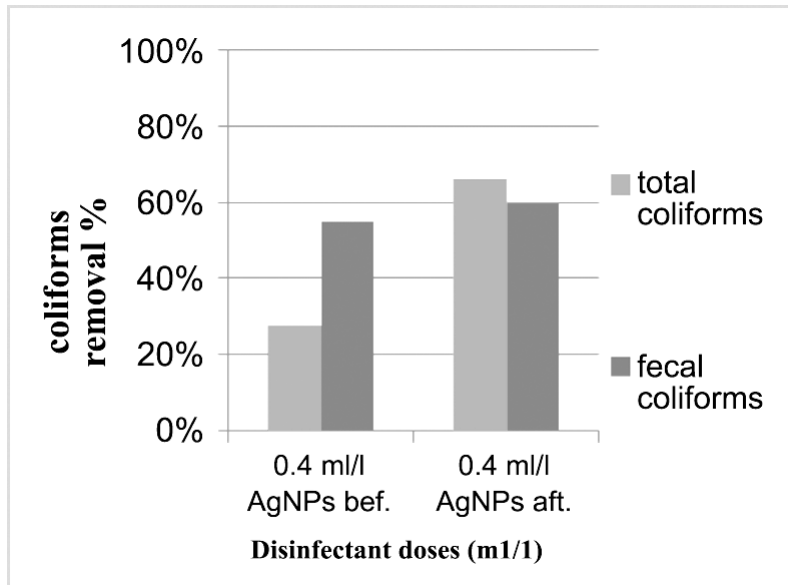

Figure (21) :Effect of on AgNPs (20nm) before and after photofragmentation on on coliforms group removal \%

\section{Figure(20) showed that:}

afterphotofragmentation by using excimerlaser on AgNPs (20 nm) To produce $\operatorname{AgNPs}(18 \mathrm{~nm})$, the removal efficiency of COD increase from nearly $47.3 \%$ before photofragmentation to $50.8 \%$ after photofragmentation, which is significant increase .

\section{Figure. (21)}

Show the effect of reduction of AgNPs sized on total and fecal coliforms.

The introduced here results showed clearly that, the effect of reduction of AgNPs size by excimer laser radiation was found to be more pronounced in the case of coliforms group than other treatment.

As the reduction of size changed the removal efficiency from $28 \%, 55 \%$ to $66 \%$, and $60 \%$ for total and fecal coliforms respectively. 


\section{References}

1- US Bureeau of reclamation and sandia national laboratories, 2003. Desalination and water purification technology roadmap a report of the executive committee water purification.

2- US Environmental protection agency, 1998b. Microbial and disinfection by-product rules. Fedral register, 63:69389 - 69476.

3- US Environmental protection agency, 1999. Alternative disinfectants and oxidants guidance manual. EPA Office of water report 815 - R - 99 - 014.

4- Abdel-Gawad S.T., 1998. 'Agricultural Drainage Water Reuse Policy: Conservation and Challenges', Proceedings of Arab Water 98, Volume 1, Cairo, Egypt, April 26-28, 1998.

5- Abdel-Gawad S.T., 1998. 'Environmental Concerns, Health Risks and Mitigation Measures of Irrigation Water Pollution', Proceedings of International Workshop on Drainage Water Reuse in Irrigation, Sharm El-Sheikh, Egypt, May 3-5, 1998.

6- Abdel-Gawad, S.T., 2001. 'The Role of Water Reuse in Sustainable Agriculture in Egypt', Regional Workshop on Water Reuse in the Middle East and North Africa, 2-5 July, Cairo, Egypt.

7- Standard Methods for the Examination of Water and Waste Water, 18th Edition, 1992, published by American Public Health Assoc., American Water Works Assoc. \& Water Environment Federation

8- J. A. Creighton, C. G. Blatchford and M. G. Albrecht, J. Chem. Soc., Faraday Trans., 75, 790 (1979)

9- P.V.Kamat,M.Fluminai,G.V.Hartland, J.Phy. chem. B 102(1998)3123.

10- Y.Badr,M.A.Mahmoud,J.Mol.Struct.749(2005)187. (excimer laser photofragmentation of metallic nanoparticles)

11- Y.Badr,M.G.AbdElWahed,M.A.Mahmoud,APPl. surf.sci.253(2006)2502. 